\title{
Nonconventional induction strategies for production of recombinant human tumor necrosis factor-alpha in Escherichia coli
}

\author{
Tapan Kumar Singha, Pooja Gulati, Sanjay Kumar* \\ Department of Microbiology, Maharshi Dayanand University, Rohtak, Haryana, India
}

ARTICLE INFO

Article history:

Received on: August 01, 2017

Accepted on: October 13, 2017

Available online: January 17, 2018

\section{Key words:}

Tumor necrosis factor-alpha,

Expression kinetics,

Auto-induction,

Thermal induction,

Salt induction,

Escherichia coli

\section{ABSTRACT}

The present study investigates the production kinetics of recombinant human tumor necrosis factor-alpha (TNF- $\alpha$ ) in Escherichia coli under three different nonconventional inducible expression systems, namely, salt, the thermal, and auto-inducible system in batch culture in a bioreactor. A codon-optimized synthetic gene of human TNF- $\alpha$ was inserted into plasmid pET-14b under T7 promoter to obtain its plasmid-based expression in E. coli. Very high specific yield ( $\sim 7 \% \%$ of total cellular protein (TCP)) was obtained with auto-inducible expression system. The thermal and salt-induced expressions could yield up to $\sim 30 \%$ and $\sim 17 \%$ of TCP, respectively. Maximum specific productivities were reported to be $0.092 \mathrm{~g} / \mathrm{gDCW} / \mathrm{h}, 0.1 \mathrm{~g} / \mathrm{gDCW} / \mathrm{h}$, and $0.079 \mathrm{~g} / \mathrm{gDCW} / \mathrm{h}$ for auto-inducible, thermal-inducible, and salt-inducible expression systems, respectively.

\section{INTRODUCTION}

Human tumor necrosis factor- $\alpha(\mathrm{TNF}-\alpha)$ is a cytokine synthesized by several blood cells such as macrophages, lymphocytes, neutrophils natural killer cells, mast cells, and eosinophils in response to any immunological challenge [1]. Human TNF- $\alpha$ belongs to TNF superfamily and plays a major role in tumor apoptosis [2,3], cachexia immune modulation, sepsis [4,5], autoimmunity, and organogenesis of secondary lymphoid organs. Due to the antitumor activity, TNF- $\alpha$ is used as a potent drug in combination with melphalan to treat soft tissue sarcoma of limbs [4]. This treatment reduces the size of tumor and thereby aids in its removal by surgery. Furthermore, TNF- $\alpha$ is a target molecule of immense pharmacological interest for the cure of other diseases such as rheumatoid arthritis and Crohn's disease occurring due to its aberrant expression profile [6]. Several TNF- $\alpha$ inhibitor-based drugs are under investigation for treating such complications $[7,8]$. In human cells, TNF- $\alpha$ is expressed as a membrane-bound protein $(21 \mathrm{kDa})$, which subsequently gets cleaved to give rise to a monomer of $17 \mathrm{kDa}$ as soluble mature protein. Structurally, TNF- $\alpha$ has three helical segments and one intrachain disulfide linkage essential for its activity [9].

*Corresponding Author

Sanjay Kumar,

Department of Microbiology,

Maharshi Dayanand University,

Rohtak, Haryana, India.

Email: sanjay.micro@mdurohtak.ac.in
Several independent studies earlier have focused on enhancing conventional expression of TNF- $\alpha$ in Escherichia coli through genetic manipulations, namely, removal of codon bias, use of strong promoters, optimum Shine-Dalgarno region, and space sequence [10-13], and fusing signal peptides [14-17]. However, the use of alternative induction strategies such as temperature-based induction, salt induction, and auto-induction remain unexplored for the production of TNF- $\alpha$ in E. coli. Induction strategies have a massive impact on growth and expression kinetics of cells and can influence overall productivity. An ideal induction strategy should be convenient, efficient, and costeffective; however, there may be some limitations. Chemical induction is easily manageable, but the inducers are quite expensive and can complicate the purification of the final product. Thermal induction of recombinant proteins is affordable and poses minimum contamination risk due to ease in changing temperature using external means only [18]. However, it can be difficult to manage culture temperature shift when used at large scale. Furthermore, heat shock can also trigger a stress response in E. coli, leading to upregulation of various proteases. Auto-induction strategy does not use expensive chemical inducers and obviates the need to monitor the growth. The cells feeding on autoinduction medium preferentially consume glucose as a carbon source, but on glucose depletion, lactose is taken up by cells and converted into allolactose, which induces the lac operon [19]. This strategy relies on culture growth and specific composition of media, and a major shortcoming remains the uncertainty about the time of induction.

The present study was thus undertaken to examine expression kinetics of human TNF- $\alpha$ in E. coli using nonconventional induction 
strategies, namely, salt, thermal, and auto-induction. To the best of our knowledge, this is the first report of expression of TNF- $\alpha$ in $E$. coli under the salt-inducible system and auto-induction system. Furthermore, the expression achieved with thermal-inducible expression system in the present study is highest of all earlier report on temperature-induced expression of recombinant human TNF- $\alpha$ (rhTNF- $\alpha$ ) in E. coli.

\section{EXPERIMENTAL}

\subsection{Material}

All cloning work was performed using standard protocols [20]. Plasmids pET-14b and pGP12 (Novagen) were obtained as a generous gift from Dr. Y. P Khasa, Microbiology Department, South Campus, University of Delhi. All routine laboratory chemicals were purchased from Hi-Media.

\subsection{Expression Plasmid}

The nucleotide sequence of Human TNF- $\alpha$ mRNA obtained from GENE BANK (accession number NM_000594) was used as a query sequence to design a codon-optimized gene employing " $E$. coli Usage Analyzer" software. The codon-optimized hTNF- $\alpha$ gene sequence (474 bp) was obtained from a commercial supplier (BioBasic, Canada). The gene insert was polymerase chain reaction amplified and subcloned into NdeI/BamHI restriction endonucleases sites of pET14b. Following two primers were used for subcloning of hTNF-alpha in plasmid $\mathrm{pET}-14 \mathrm{~b}$.

Forward: 5'-GGAATTCCATATGGTCAGATCATCTTCT-3'

Reverse: 5'-CGGGATCCTCACAGGGCAATGAT-3'.

\subsection{Sandwich ELISA}

rhTNF- $\alpha$ was detected by performing qualitative sandwich ELISA (ELISA kit from R\&D systems). The assay was performed as per the instructions provided by the manufacturer. Samples were prepared by lysing the cell pellets with $1 \mathrm{ml}$ saline containing $2 \%$ sodium dodecyl sulfate (SDS) followed by boiling for 1-2 min. This whole cell lysate was serially diluted in water for ELISA and OD was measured at $450 \mathrm{~nm}$.

\subsection{Protein Quantification}

Gel densitometry: The protein was quantified by the gel densitometry method. The whole cell lysate was centrifuged at $1000 \mathrm{rpm}$ for 10 min, and the samples of supernatants were run on $12 \%$ SDSpolyacrylamide gel electrophoresis (PAGE) gel. The gels were stained with Coomassie blue and visualized using gel documentation system. Band intensities were analyzed using Quantity One software (Bio-Rad $\mathrm{Lab}$ ), and absolute protein concentrations were estimated using BSA standard plot.

\subsection{Plasmid Stability Test}

Culture samples collected at different time interval were diluted in appropriate ratios and aliquots were spread on Luria Broth (LB) agar plate. Randomly, $\sim 50$ colonies were picked from the overnight incubated plate and transferred to LB agar plate supplemented with ampicillin $(100 \mu \mathrm{g} / \mathrm{ml})$. The colonies growing on antibiotic supplemented plate accounted for the recombinant cells carrying plasmid pET-14b-TNF- $\alpha$.

\subsection{Batch Processes in the Bioreactor}

A single colony of recombinant $E$. coli cells from overnight incubated LB agar plate was used to inoculate $5 \mathrm{ml} \mathrm{LB}$ supplemented with appropriate antibiotics. It was grown overnight at $37^{\circ} \mathrm{C}$ under shaking conditions $(220 \mathrm{rpm})$. The overnight culture was used to inoculate $200 \mathrm{ml}$ fresh sterile media, distributed $50 \mathrm{ml}$ each in four separate $500 \mathrm{ml}$ Erlenmeyer flasks. The inocula for different batches in bioreactor were raised in the respective batch media and an inoculum size of $10 \% \mathrm{v} / \mathrm{v}$ was used.

\subsubsection{Batch cultivation in bioreactor}

All the batch cultivations were performed in a $5 \mathrm{~L}$ bioreactor with $2 \mathrm{~L}$ working volume. Culture parameters such as $\mathrm{pH}$ and dissolved oxygen concentrations were controlled at 7 and $30 \%$, respectively, for all batch experiments. Aeration rate was fixed at $1 \mathrm{VVM}$ for the entire period of cultivation in all the batches. The temperature was controlled at $37^{\circ} \mathrm{C}$ in all batches except for thermal-inducible expression system, where the pre-induction culture was maintained at $30^{\circ} \mathrm{C}$.

\subsubsection{Auto-inducible expression}

Auto-induction of plasmid pET-14b-TNF- $\alpha$ was achieved in BL21(DE3) by growing cells in $2 \mathrm{~L}$ terrific broth auto-induction medium $(0.5 \mathrm{~g} / \mathrm{L}$ glucose, $2 \mathrm{~g} / \mathrm{L}$ lactose, $12 \mathrm{~g} / \mathrm{L}$ bactotrypton, $24 \mathrm{~g} / \mathrm{L}$ yeast extract, $6.8 \mathrm{~g} / \mathrm{L} \mathrm{KH}_{2} \mathrm{PO}_{4}, 7.1 \mathrm{~g} / \mathrm{L} \mathrm{Na}_{2} \mathrm{HPO}_{4} .12 \mathrm{H}_{2} \mathrm{O}, 0.15 \mathrm{~g} / \mathrm{L}$ $\left.\mathrm{MgSO}_{4}, 3.3 \mathrm{~g} / \mathrm{L}[\mathrm{NH} 4]_{2} \mathrm{SO}_{4}\right)$ in bioreactor. The samples were collected after every hour, and cell pellets were stored at $-20^{\circ} \mathrm{C}$ for further analysis.

\subsubsection{Thermal-inducible expression}

The system used for thermal-inducible expression was earlier developed by Tabor and Richardson [21]. DH5 $\alpha$ cells of E. coli were cotransformed with plasmids pGP12 and pET-14b-TNF- $\alpha$. The plasmid pGP12 carried a gene of T7 RNA polymerase downstream of lambda promoter under strong negative control of a repressor protein. $5 \mathrm{ml}$ LB medium (supplemented with $50 \mu \mathrm{g} / \mathrm{ml}$ kanamycin and $100 \mu \mathrm{g} / \mathrm{ml}$ ampicillin) was inoculated with a single colony of transformed cells and incubated overnight at $30^{\circ} \mathrm{C}$ under shaking conditions $(220 \mathrm{rpm})$. Secondary inoculum and batch culture were grown at $30^{\circ} \mathrm{C}$ in $\mathrm{TB}$ medium supplemented with both the antibiotics. As the cell density in batch culture reached $\sim 2 \mathrm{OD}_{600}$, the culture was induced by upshifting the temperature to $42^{\circ} \mathrm{C}$ for $5 \mathrm{~min}$. After induction, the culture was maintained at $37^{\circ} \mathrm{C} .1 \mathrm{ml}$ culture samples were drawn after every hour, harvested and stored for further analysis.

\subsubsection{Salt-inducible expression}

The salt-based expression system employed GJ1158 cells of E. coli as expression host carrying osmoresponsive promoter for synthesis of T7 RNA polymerase [22]. Competent cells of E. coli GJ1158 were transformed with pET-14b-TNF- $\alpha$ and grown in salt-free LB medium $(2 \mathrm{~L})$ in $5 \mathrm{~L}$ bioreactor under controlled conditions. The culture was induced at an $\mathrm{OD}_{600} \sim 0.6$ and post-induction culture samples were collected every hour and stored at $-20^{\circ} \mathrm{C}$ for further analysis.

\subsection{Cell Lysis and Inclusion Bodies Isolation}

The cells were harvested from $50 \mathrm{ml}$ culture through centrifugation at $10,000 \mathrm{rpm}$ and stored at $-20^{\circ} \mathrm{C}$. The $20 \mathrm{mg}$ cell pellet was suspended in $2 \mathrm{ml}$ of freshly prepared lysis buffer ( $50 \mathrm{mM}$ Tris-HCl, $5 \mathrm{mM}$ EDTA, $1 \mathrm{mM}$ phenylmethylsulfonyl fluoride, and $\mathrm{pH} 8.5$ ). The cells were lysed by sonication and inclusion bodies were separated by spinning the cell lysate at $1000 \mathrm{rpm}$ for $15 \mathrm{~min}$ at $4^{\circ} \mathrm{C}$. The inclusion bodies were washed thrice with $1 \%$ deoxycholate in Tris buffer. 


\subsection{Purification and Refolding of TNF- $\alpha$}

The inclusion bodies were suspended in solubilization buffer $(40 \mathrm{mM}$ Tris buffer, $8 \mathrm{M}$ urea) and kept overnight under shaking at $4^{\circ} \mathrm{C}$. The solubilized protein was passed through a $4 \mathrm{ml}$ of nickel-nitrilotriacetic acid (NTA) column, preequilibrated with solubilization buffer. The column was washed with $20 \mathrm{ml}$ of wash buffer (10 mM Tris buffer, $8 \mathrm{M}$ Urea, and $\mathrm{NaCl} 10 \mathrm{mM}$ imidazole). His-tagged protein was eluted by passing $5 \mathrm{ml}$ of solubilization buffer containing $300 \mathrm{mM}$ imidazole. The purified protein was refolded using dilution refolding method as described earlier [9].

\subsection{Bioassay of $\operatorname{rhTNF}-\alpha$}

The refolded protein was tested for biological activity by performing a cytotoxicity assay against L-929 mouse fibroblast cells using the method as described earlier [23].

\section{RESULTS AND DISCUSSION}

A codon-optimized synthetic gene of human TNF- $\alpha$ was cloned between NdeI and BamHI sites of plasmid pET-14b [Figure 1]. This plasmid construct (pET-14b-TNF- $\alpha$ ) was used to examine expression kinetics of rhTNF-alpha during the batch process in the bioreactor. SDS-PAGE analysis of samples of all induced culture showed an intense band of $\sim 20 \mathrm{kDa}$, which matched with the expected size of Histagged rhTNF- $\alpha$ [Figure 2]. The protein was further confirmed to be rhTNF- $\alpha$ by performing a sandwich ELISA of the whole cell lysates of culture samples. The cells were lysed through sonication, and protein was localized in the cell. The entire protein content was found to be present in the cell pellet fraction as inclusion bodies. Intracellular protein concentrations were determined by densitometry method, and specific yield, volumetric product yield, and specific productivity were calculated.

\subsection{Expression Kinetics of Auto-induced rhTNF- $\alpha$}

Cells induced automatically after 5 hours of growth in batch culture in $2 \mathrm{~L} \mathrm{~TB}$ medium with a maximum volumetric product yield of $\sim 1.0 \mathrm{~g} / \mathrm{L}$ [Figure 3a]. The highest value of specific productivity was found to be $\sim 0.0925 \mathrm{~g} / \mathrm{gDCW} / \mathrm{h}$ at $2^{\text {nd }} \mathrm{h}$ post-induction after which it declined during the subsequent hours [Figure $3 \mathrm{~b}$ ]. The protein content accumulated up to $0.239 \mathrm{~g} / \mathrm{gDCW}$ within $4 \mathrm{~h}$, post-induction after which marginal increase was observed for the subsequent $2 \mathrm{~h}$ [Figure $3 \mathrm{c}$ ]. The total biomass reached up to an OD of $\sim 10.5$ [Figure $3 \mathrm{~d}$ ]. Plasmid pET$14 \mathrm{~b}-\mathrm{TNF}-\alpha$ was found to be stable throughout the cultivation period. High expression of rhTNF- $\alpha$ obtained with auto-induction strategy proved that the expression efficiency was not limited due to any factor at transcriptional and translational levels. However, a major limitation of auto-induction can be the uncertainty of induction time which is very crucial, as early induction can keep cells from attaining high cell density causing low volumetric product yields.

\subsection{Expression Kinetics of Thermal-induced rhTNF- $\alpha$}

Thermal induction yielded relatively less protein as compared to the above two induction strategies with maximum specific product yield reaching up to $\sim 0.160 \mathrm{~g} / \mathrm{g}$ DCW $(\sim 32 \%$ of total cellular protein content) within $6 \mathrm{~h}$ post-induction [Figure $3 \mathrm{c}$ ]. The specific productivity was reported to be highest at $1^{\text {st }} \mathrm{h}$ with a value of $\sim 0.1 \mathrm{~g} /$ $\mathrm{gDCW} / \mathrm{h}$ [Figure 3b]. The maximum volumetric yield was $0.625 \mathrm{~g} / \mathrm{L}$ at $6^{\text {th }} \mathrm{h}$ after induction [Figure 3a]. Plasmid remained stable throughout the cultivation period. Thermal induction strategy is ideal for largescale production as it does not demand expensive chemical inducers or

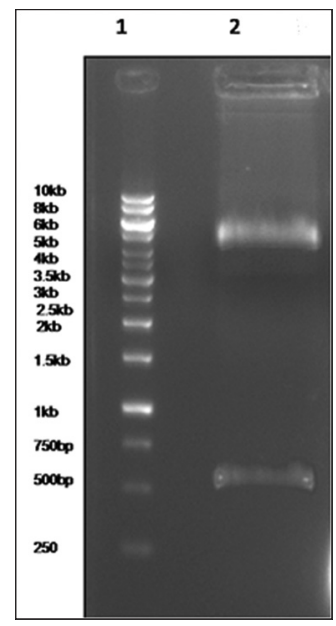

Figure 1: Agarose gel (1\%) electrophoresis: Lane 1: DNA ladder; Lane 2: Plasmid pET-14b- tumor necrosis factor-alpha doubly digested with NdeI and BamHI restriction endonucleases.

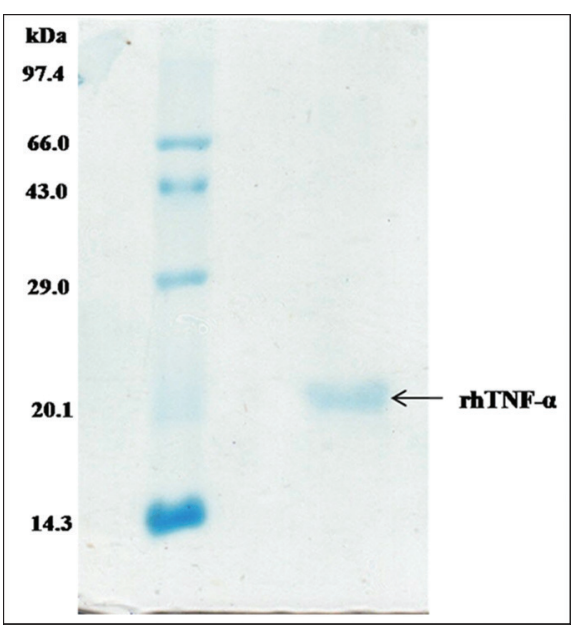

Figure 2: 12\% sodium dodecyl sulfate-polyacrylamide gel electrophoresis showing purified recombinant human tumor necrosis factor-alpha after nickelnitrilotriacetic acid column chromatography.

specific media type and the culture can be induced at the appropriate time by using outer means thereby reducing the risk of contamination. However, the heat induction triggers heat shock response in the cells which could probably be the reason of relatively poor expression $(\sim 0.160 \mathrm{~g} / \mathrm{g}$ DCW) of thermally induced rhTNF- $\alpha$ [24]. The expression level of heat-induced rhTNF- $\alpha$ achieved in the present study was $\sim 30$ folds higher than that of an earlier report on the similar system [18].

\subsection{Expression Kinetics of Salt-induced rhTNF- $\alpha$}

The maximum specific yield was found to be $0.085 \mathrm{~g} / \mathrm{gDCW}$ at $3^{\text {rd }} \mathrm{h}$ post-induction, and no further significant increase was observed during subsequent hours. The values of maximum volumetric yield and specific productivity were $0.102 \mathrm{~g} / \mathrm{L}$ and $0.079 \mathrm{~g} / \mathrm{gDCW} / \mathrm{h}$, respectively, at $4^{\text {th }}$-h and $2^{\text {nd }}$-h post-induction. The plasmid was found to be completely stable throughout the cultivation. The poor expression of rhTNF- $\alpha(0.085 \mathrm{~g} / \mathrm{gDCW})$ in GJ1158 cells of $E$. coli in response to salt induction could be due to several reasons. It might be due to (1) poor expression of RNAP under proU promoter, (2) poor cell growth due to poor composition of medium (salt-free), and (3) consumption of salt 

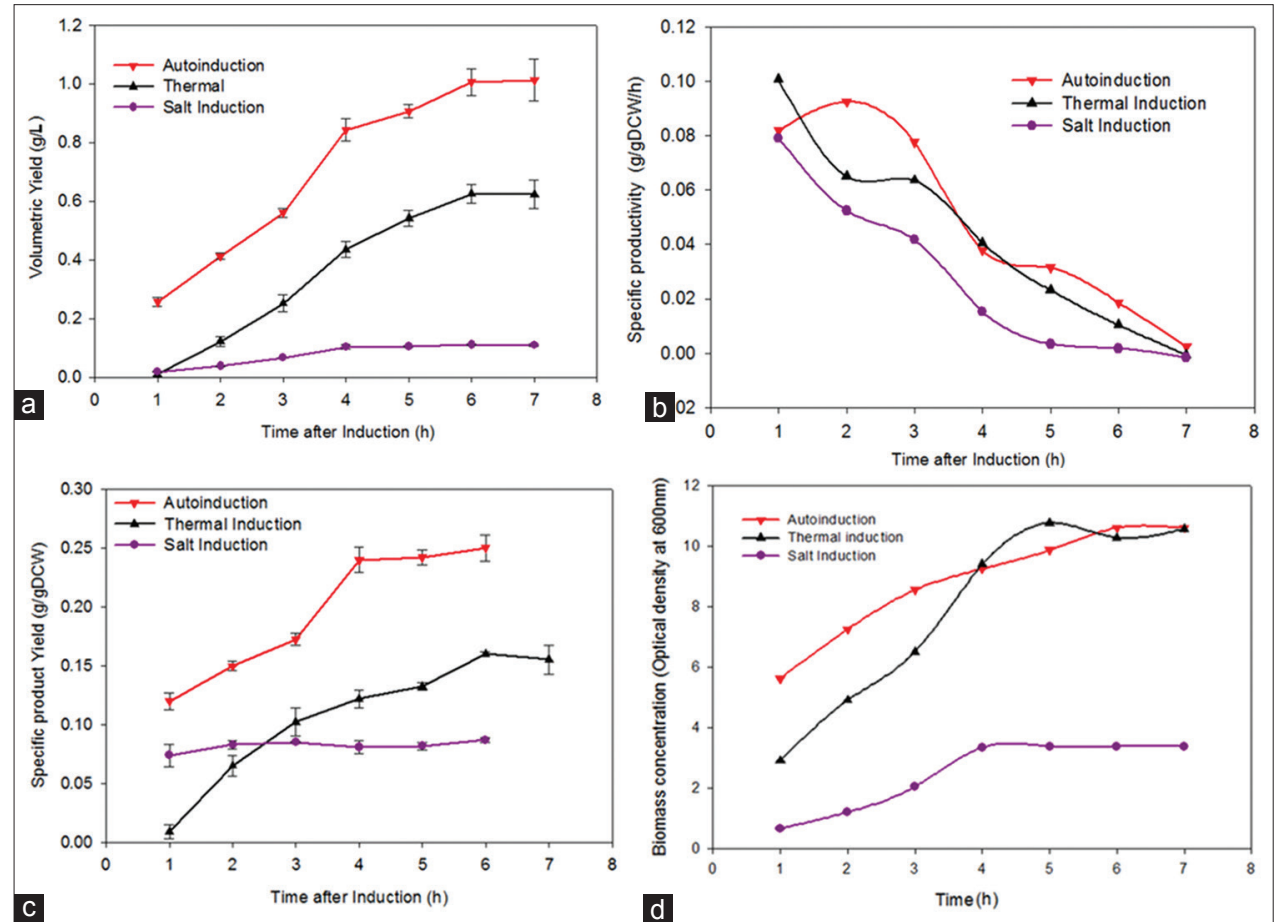

Figure 3: Expression kinetics of recombinant human tumor necrosis factor-alpha inclusion bodies in Escherichia coli with different induction strategies employed during different batch cultivations in the bioreactor. (a) Volumetric product yield (g/L); (b) specific productivity (g/gDCW/h); (c) specific product yield $(\mathrm{g} / \mathrm{gDCW})$; and (d) optical density of culture $(600 \mathrm{~nm})$. Error bars represent standard deviations from triplicates

by cells during growth thereby lowering the osmolarity of the medium. Relatively poor biomass yield obtained in the salt-inducible system can be explained by the poor composition of salt-free LB medium.

\subsection{Purification and Refolding of rhTNF- $\alpha$}

The benefit of high expression efficiency of 77 promoter-based system is undermined by the poor solubility of the recombinant protein. Very high protein synthesis rates often lead to protein aggregation due to (1) lack of timely interaction of protein folding intermediates with folding mediators and (2) blocking of translocation pathways thereby preventing the protein from reaching the compartments with the less reducing environment. The overall yield of biologically active protein in such systems is dictated by the efficiency of in vitro refolding procedures. The expressed rhTNF-alpha accumulated as an insoluble inclusion body in the cytoplasm with a negligible soluble fraction. Inclusion bodies of TNF- $\alpha$ were extracted by cell lysis through sonication and purified by repeated washing with deoxycholate. Inclusion bodies were solubilized using a denaturing buffer containing $8 \mathrm{M}$ Urea and purified by passing through nickel-NTA column. A protocol of dilution refolding as described in an earlier report was followed for refolding of inclusion bodies obtained from various experiments. The refolding procedure employed in this study yielded $43 \%$ soluble protein from denatured protein eluted from Nickel-NTA column [Figure 2]. The MTT tetrazolium cytotoxic assay was performed against murine L929 cell line to observe antitumor activity in the different samples of purified refolded TNF- $\alpha$. A dose-dependent fall in the viability of murine L929 cells was reported in response to the rhTNF- $\alpha$ application.

\section{CONCLUSION}

The present study examined the expression kinetics of rhTNF- $\alpha$ under $\mathrm{T} 7$ promoter-based system using three different nonconventional induction strategies. The initial specific productivity observed in different systems ranged from $0.08 \mathrm{~g} / \mathrm{gDCW} / \mathrm{h}$ to $0.12 \mathrm{~g} / \mathrm{gDCW} / \mathrm{h}$ showing that expression of the protein was strongly induced in all expression systems. However, the final yields in the different system were governed by subsequent fall in growth and product formation rates. The observed decline in specific productivity with time was expected as recombinant protein synthesis competes for ribosomal binding sites, amino acids, and other precursors with housekeeping proteins of cells and thereby puts the metabolic burden on protein producing cells $[25,26]$. Auto-induction system was found to be superior with maximum productivity, followed by thermal-inducible and salt-inducible systems. The protein was purified using Ni-Affinity Chromatography. The average recovery yield of in vitro refolding procedure was $\sim 42 \%$.

\section{ACKNOWLEDGMENT}

The financial support (grant no. UGC-MRP 41-571 sanctioned to Dr. Sanjay Kumar) received from University Grant Commission is highly acknowledged. The support from Dr. Y. P Khasa, (Microbiology Department, South Campus, University of Delhi), is highly appreciated.

\section{REFERENCES}

1. Dubravec DB, Spriggs DR, Mannick JA, Rodrick ML. Circulating human peripheral blood granulocytes synthesize and secrete tumor necrosis factor alpha. Proc Natl Acad Sci U S A 1990;87:6758-61.

2. Carswell EA, Old LJ, Kassel RL, Green S, Fiore N, Williamson B. An endotoxin-induced serum factor that causes necrosis of tumors. Proc Natl Acad Sci U S A 1975;72:3666-70.

3. Creasey AA, Reynolds MT, Laird W. Cures and partial regression of murine and human tumors by recombinant human tumor necrosis factor. Cancer Res 1986;46:5687-90. 
4. Ghezzi P, Cerami A. Tumor necrosis factor as a pharmacological target. Mol Biotechnol 2005;31:239-44.

5. Beutler B, Cerami A. Cachectin (tumor necrosis factor): A macrophage hormone governing cellular metabolism and inflammatory response. Endocr Rev 1988;9:57-66.

6. Moss ML, Sklair-Tavron L, Nudelman R. Drug insight: Tumor necrosis factor-converting enzyme as a pharmaceutical target for rheumatoid arthritis. Nat Clin Pract Rheumatol 2008;4:300-9.

7. Chang J, Girgis L. Clinical use of anti-TNF-alpha biological agents - a guide for GPs. Aust Fam Physician 2007;36:1035-8.

8. Reinhart K, Karzai W. Anti-tumor necrosis factor therapy in sepsis: Update on clinical trials and lessons learned. Crit Care Med 2001;29 7 Suppl: S121-5.

9. Davis JM, Narachi MA, Alton NK, Arakawa T. Structure of human tumor necrosis factor alpha derived from recombinant DNA. Biochemistry 1987;26:1322-6.

10. Marmenout A, Fransen L, Tavernier J, Van der Heyden J, Tizard R, Kawashima E, et al. Molecular cloning and expression of human tumor necrosis factor and comparison with mouse tumor necrosis factor. Eur J Biochem 1985;152:515-22.

11. Wang D, Shi L. High-level expression, purification, and in vitro refolding of soluble tumor necrosis factor-related apoptosis-inducing ligand (TRAIL). Appl Biochem Biotechnol 2009;157:1-9.

12. Lü Z, Wang Z, Ming Y, Bao H, Liu X. High-level expression of the human tumor necrosis factor-alpha. Chin J Biotechnol 1995;11:37-44.

13. Yamada M, Furutani Y, Notake M, Yamagishi UI, Yamayoshi M, Fukui T, et al. Efficient production of human tumour necrosis factor in Escherichia coli. J Biotechnol 1985;3:141-53.

14. Dobrynin VN, Berkova NP, Boldyreva EF, Bystrov NS, Kravchenko VV. Expression in Escherichia coli of DNA coding for human tumor necrosis factor. Bioorg Khim 1988;14:1530-7.

15. Nakamura S, Masegi T, Kitai K, Ichikawa Y, Kudo T, Aono R, et al. Extracellular production of human tumor necrosis factor-alpha by Escherichia coli using a chemically-synthesized gene. Agric Biol Chem 1990;54:3241-50.

16. Lin Z, Lei H, Cao P. Expression, purification, and in vitro refolding of soluble tumor necrosis factor-related apoptosis-inducing ligand (TRAIL). Protein Expr Purif 2007;51:276-82.

17. Han W, Zhang Y, Yan Z, Shi J. Construction of a new tumour necrosis factor fusion-protein expression vector for high-level expression of heterologous genes in Escherichia coli. Biotechnol Appl Biochem 2003;37:109-13.

18. Menart V, Jevsevar S, Vilar M, Trobis A, Pavko A. Constitutive versus thermoinducible expression of heterologous proteins in Escherichia coli based on strong PR,PL promoters from phage lambda. Biotechnol Bioeng 2003;83:181-90.

19. Studier FW. Protein production by auto-induction in high density shaking cultures. Protein Expr Purif 2005;41:207-34.

20. Sambrook J, Green MR. Molecular Cloning: A Laboratory Manual. New York: Cold Spring Harbor Laboratory Press, Cold Spring Harbour; 2012. p. 157-210.

21. Tabor S, Richardson CC. A bacteriophage T7 RNA polymerase/ promoter system for controlled exclusive expression of specific genes. Proc Natl Acad Sci U S A 1985;82:1074-8.

22. Bhandari P, Gowrishankar J. An Escherichia coli host strain useful for efficient overproduction of cloned gene products with $\mathrm{NaCl}$ as the inducer. J Bacteriol 1997;179:4403-6.

23. Zhang C, Liu Y, Zhao D, Li X, Yu R, Su Z. Facile purification of Escherichia coli expressed tag-free recombinant human tumor necrosis factor alpha from supernatant. Protein Expr Purif 2014;95:195-203.

24. Grossman AD, Erickson JW, Gross CA. The htpR gene product of $E$. coli is a sigma factor for heat-shock promoters. Cell 1984;38:383-90.

25. Weber J, Hoffmann F, Rinas U. Metabolic adaptation of Escherichia coli during temperature-induced recombinant protein production: 2 . Redirection of metabolic fluxes. Biotechnol Bioeng 2002;80:320-30.

26. Singha TK, Gulati P, Mohanty A, Khasa YP, Kapoor RK, Kumar S. Efficient genetic approaches for improvement of plasmid based expression of recombinant protein in Escherichia coli: A review. Process Biochem 2017;55:17-31.

How to cite this article:

Singha TK, Gulati P, Kumar S. Nonconventional induction strategies

for production of recombinant human tumor necrosis factor-alpha in

Escherichia coli. J App Biol Biotech. 2018;6(1):23-27.

DOI: 10.7324/JABB.2018.60105 